\title{
The effect of women's care-giving role on their social security rights
}

\author{
KITTY MALHERBE* \& LORENZO WAKEFIELD** \\ *Senior Lecturer, Faculty of Law, University of the Western Cape \\ **Researcher, Children's Rights Project, Community Law Centre, University of \\ the Western Cape
}

\section{INTRODUCTION}

The South African Constitution, 1996, guarantees 'everyone' the right of access to social security, including social assistance, if they are unable to support themselves and their dependants. ${ }^{1}$

South African social security can generally be divided into two branches: social assistance and social insurance. ${ }^{2}$ Social assistance in South Africa refers to tax based, flat rate and means tested benefits administered by the state and payable to select categories of persons in need of income support, for example, grants paid to older persons. Social insurance, on the other hand, comprises of contributory schemes that provide income related benefits to employees in the event of a specific social risk occurring, for example, unemployment benefits payable upon loss of employment, or benefits payable upon retirement. ${ }^{3}$

Whereas social assistance legislation provides benefits for care-givers, there are a number of provisions in social insurance legislation that indirectly exclude care-givers from the protection against social risks, such as, retirement, unemployment and workplace injuries. ${ }^{4}$ In many instances there is a strong correlation between the groups of people that are excluded and the care-giving role they fill.

For the purposes of this article the concept 'care-givers' includes, but is not limited to, 'primary care-givers' in terms of the Social Assistance Act 13 of

1 Section 27.

2 The traditional classification of social security as either social assistance or social insurance will be followed in this article, as the relative advantages or disadvantages of being a female care-giver correspond to this division. The wider concept of social protection denoting 'a system of general welfare support and protection' is increasingly used alongside the two branches of social security identified above (Olivier 'The concept of social security' in Olivier et al (eds) Introduction to social security (2004) 14-15).

3 See Pieters Basic principles of social security (1993) 5-7; Olivier et al (eds) (n 2 above) 14 n 4.

4 The exclusion of women from the scope of application of social insurance mainly occurs indirectly. 
2004 (SAA) ${ }^{5}$. Although the marginalisation of care-givers affects both male and female care-givers, the aim of this article is to illustrate that women as caregivers are doubly burdened. Hence, women who care for family members on a full time basis are the primary focus of this article.

The main focus of the article is the extent to which the different social security schemes provide for care-givers, and particularly women as care-givers. There are some instances where women's care-giving role provides them with access to benefits which they otherwise would not have had. On the other hand, care-giving responsibilities may exclude women from other benefits. In addition to South African social security legislation, the treatment of women and their care-giving role in selected international and regional instruments, which were either signed or signed and ratified by South Africa, will be considered. These instruments are included as they place a legal obligation on the South African government to adopt measures (including social security measures) to address the inherent inequality that women, especially female care-givers, face in comparison to men.

However, in determining the gaps in the provision of support to female care-givers, one has to be mindful of the dangers of unfair discrimination against male care-givers and of stereotyping women in general as care-givers. This article, therefore, will also refer to selected case law where the issues of the constitutionality of measures intended to benefit older women, and of gender stereotyping, were discussed. The aim is, therefore, to determine whether the caution against gender stereotypes should detract from measures aimed at improving the lives of female care-givers.

\section{ACCESS OF CARE-GIVERS TO STATE GRANTS}

A number of the social assistance grants payable in terms of the SAA are paid to persons taking care of children or other family members. Although only the benefits payable to adults caring for children are generally classified as 'family benefits', this article will show that women's care-giving duties extend to caring for other family members as well. Many care-giving responsibilities are determined by the composition of the family in question. 'Nuclear' families consisting of a father and mother and a number of their own biological children are not the norm in contemporary South African society. ${ }^{6}$ Instead, families are far more likely to consist of extended families, families headed by single parents, child headed households, and grandmothers in the rural areas taking care of their grandchildren.

The grants payable to families, therefore, have to reflect the more prevalent family structures. As an illustration, this part of the article will focus on a family consisting of a grandmother taking care of her grandchildren in a rural

5 The child support grant is payable to the primary care-giver of a child under the age of 15 . The primary care-giver is the person responsible for taking care of the daily needs of the child and, therefore, includes persons other than the parents of the child.

6 Guthrie 'Children/family' in Olivier et al (eds) (n 2 above ) 343. 
area. Whereas one would expect that older persons ${ }^{7}$ in rural areas would be able to rely on their families for financial support and care, this is far removed from the reality of the breakdown of traditional family support caused by urbanisation and unemployment. ${ }^{8}$ Instead of older persons being cared for by their families, they end up assuming the childcare burden of their urbanised children.

A grandmother taking care of her grandchildren could, first, qualify for social assistance in the form of a child support grant, should she be able to meet the requirements for receipt of the grant. A child support grant is paid to the primary care-giver of a child under the prescribed age. ' 'Primary caregiver' is defined as any person who in fact provides for the basic and daily care needs of the child. ${ }^{10}$ A primary care-giver of a child may, therefore, not necessarily be the parent of that child, and thus a grandmother in whose care her grandchildren were left would qualify as a primary care-giver. She would be entitled to the grant for up to six of her grandchildren in her care. ${ }^{11}$ It is, therefore, her role as care-giver of the child that entitles her to the grant to the exclusion of the child's parents ${ }^{12}$.

The child support grant is means tested and intended for the poorest among families. As levels of poverty are generally higher in rural areas, among Africans and in female headed households ${ }^{13}$, this grant is ideally targeted at the situation of the hypothetical grandmother in a rural area acting as primary care-giver of her grandchildren.

Whereas the child support grant provides support to families raising children in poverty, other family benefits are intended for families raising children who are vulnerable for different reasons. Many South African children need alternative care, such as foster care, when it is not in their best interest to remain in their parental home. Social assistance is provided to foster parents $^{14}$ in the form of the foster child grant. More often than not women end up with the burden of caring for foster children, and the time spent on care-

7 The term in South African legislation that has replaced phrases, such as, 'aged persons' and 'the elderly'. In terms of the SAA (before it was amended by the Social Assistance Amendment Act 6 of 2008) an older person was defined as a woman over the age of 60 and a man over the age of $65-\mathrm{s}$ 1. The same differentiation is found in the Older Persons Act 13 of 2006. Recent developments regarding the differentiation in pensionable age are discussed below.

8 Malherbe 'Inter-generational solidarity and caring for the aged' in Olivier et al (eds) The extension of social protection in South Africa (2001) 204-206.

9 Section 6 SAA. From January 2009 the grant will be payable for children under the age of 15, but the age until which children can qualify is progressively being rolled out on an annual basis, with the final aim being to make the grant payable for children under the age of 18 - Department of Social Development 'Child support grant' http://www.dsd.gov.za (accessed 2010/01/07).

10 Section 1 SAA.

11 Guthrie (n 6 above) 359. Biological or adoptive parents can receive the grant for all of their own children for whom they are the primary care-givers.

12 According to the National report on the status of older people (2002) para 2.1, households in the Eastern Cape, KwaZulu-Natal and Limpopo are more likely to be headed by older women than older men. In the Western Cape 95\% (on average) of the care-givers are female - http://www.sarpn.org.za/ documents/d0001082/Executive_Summary.pdf (accessed 21/05/2008).

13 Olivier (n 2 above) 8.

14 'Foster parent' is defined in s 1 SAA as 'a person, except a parent of the child concerned, in whose custody a foster child has been placed in terms of any law ...'. 
giving keeps them from entering the labour market. Even though the female foster parent receives the foster grant, the grant is intended to assist her to take care of the child. The grant is not large enough so that she can save for her own retirement funding. However, for a grandmother in whose foster care her grandchildren are officially placed, this grant would be additional to her own older person's grant. ${ }^{15}$

Perhaps the most vulnerable children are those suffering from severe physical and/or mental disability. For this reason the care dependency grant is payable to the parent, foster parent or primary care-giver of a child that is so severely disabled that he or she needs permanent home care or support services. ${ }^{16}$ This grant, therefore, provides specifically for someone that takes full time care of a disabled child, and who is consequently excluded from social insurance benefits and from providing for their own retirement. Should the grandmother mentioned above be caring for a disabled grandchild, this care-giving role, therefore, entitles her to benefit from this grant. ${ }^{17}$

\section{OLDER WOMEN AND THE OLDER PERSON'S GRANT}

In each of the above cases it is the grandmother's care-giving role that entitles her to payment of the grants. The grants available to her are, however, not limited to grants for the children in her care. She is also entitled to an older person's grant for herself.

The older person's grant is a grant payable to 'older persons'. 'Older persons' used to be defined as women aged 60 and older, and men from age $65 .{ }^{18}$ The definition has been amended in $2008^{19}$ to progressively lower the qualifying age for older men to age 60. The older person's grant is means tested and is, therefore, the ideal vehicle to provide retirement income for persons who were unable to provide for their own retirement. This grant has also been credited with a marked increase in disposable income for households where older persons reside. ${ }^{20}$

What then is the significance of the older person's grant in the context of female care-givers? The older person's grant is the only independent income ${ }^{21}$ available to women who reach retirement age and who have had no, or limited, opportunity to save for their own retirement during their economically active years due to their care-giving responsibilities.

15 See below for more on the older person's grant. The foster child grant currently is R680 per month compared to the child support grant of only R240 per month per child - SASSA http://www.sassa.gov. za (accessed 2010/01/07).

16 Section 7 SAA.

17 Currently R1010 per month.

18 Section 10 SAA.

19 Social Assistance Amendment Act 6 of 2008.

20 Olivier 'Old age and retirement provision' in Olivier et al (eds) (n 2 above) 275 cites a number of studies that came to the following conclusions: the older person's grant reduces the poverty gap for older persons by 94 per cent, and the grant in some instances supports entire households of up to three generations.

21 Currently R1010 per month. 
The National report on the status of older people states the following about the fact that women constitute the majority of the beneficiaries of the older person's grant:

'The high proportion of women receiving the social grant is due to the fact that women enter the system earlier than men and also stay in the system for a longer time due to their longevity. It is also indicative of the fact that women in South Africa are more vulnerable to poverty than men during their economically active period. ${ }^{22}$

Both the SAA ${ }^{23}$ and the Older Persons Act $^{24}$ used the same definition of an 'older person', ie a 65 year or older male and a female 60 years of age or older. As a consequence women qualified for older person's grants at 60 but men had to wait until they turn 65 before they could apply. It is this differentiation between females and males which was central to the predicament of four unemployed Eastern Cape men, Messrs Roberts, Whitebooi, Casling and Visagie, all between the ages of 60 and 65. All four would have qualified for the grant had they been female. ${ }^{25}$ This led to a challenge in 2005 in the Pretoria High Court ${ }^{26}$ to the age differentiation in terms of which men and women qualify for the older persons grant. The Court was asked to amend the SAA in order that the qualifying age for both men and women could be equalised at 60 .

The differentiation in the qualifying age is not a recent development. When the first old age pensions were introduced in South Africa in terms of the Old Age Pensions Act 22 of 1928, the pensionable age for both men and women was fixed at $65 .{ }^{27}$ After severe cutbacks in old age pensions as a result of the Great Depression, the post-Depression economic recovery led the Minister of Finance to propose the expansion of the provision of benefits by lowering the pensionable age of women to $60 .{ }^{28}$ This differentiation, which originated in the Old Age Pension Amendment Act ${ }^{29}$, was carried through in subsequent legislation 'without motivation being provided at any stage for its existence and perpetuation'. ${ }^{30}$ Despite criticism of the differentiation ${ }^{31}$, it was once again included in the 2004 SAA. ${ }^{32}$

22 National report on the status of older people (2002) para 3.1. This statement confirms the 'continuation of feminisation of poverty in old age' - Olivier (n 20 above) 275. According to Woolard Impact of government programmes using administrative data sets (2003) 3, in 2003 more than twice as many women as men qualified for a grant.

23 Section 10.

24 Act 13 of 2006.

25 They, in addition, maintained that their dignity had been violated because they have to rely on their wives' grants - Matyu J 'Men challenge ruling which allows women earlier pensions' The Herald (16 September 2005).

26 Roberts and Others $v$ Minister of Social Development and Others (Case 32838/05 TPD). At the time of writing the judgment is still pending, although the offending legislation has subsequently been amended as a proactive step by Parliament.

27 Kruger 'Come back when you are 65, Sir': Discrimination in respect of access to social assistance for the elderly' (2006) 4 LDD 71.

28 Kruger (n 27 above) 72.

29 Section 1 Old Age Pension Amendment Act 34 of 1937.

30 Kruger (n 27 above) 72.

31 See Olivier et al 'Constitutional issues' in Olivier et al (eds) Social security:A legal analysis (2003) 97.

32 Section 10. 
The challenge to the differentiation between the pensionable ages of men and women relied on the infringement of two rights: the right to equality ${ }^{33}$ and the right of access to social security of men older than 60. According to the Grootboom case ${ }^{34}$ socio-economic rights, such as the right of access to social security, must be interpreted in context, taking into consideration the textual setting, as well as the historical and social context of the particular right.

Section 27(2) of the Constitution places a positive obligation upon the state to take all reasonable legislative and other measures to achieve the progressive realisation of the right of access to social assistance. ${ }^{35}$ Any legislation or scheme would have to be reasonable and effective in its conception as well as implementation, and respond to the needs of particularly desperate people, before it can be considered to be 'reasonable' in the context of the Bill of Rights. ${ }^{36}$ Although based on different facts, the ratio of the Constitutional Court in the Khosa case ${ }^{37}$ and specifically Mokgoro J's views on the relationship between equality and the reasonableness of a particular scheme, are instructive for the present discussion. In the Khosa case Makgoro J found that as 'everyone' is entitled to the right of access to social assistance, any limitation placed on access to grants must be reasonable and consistent with the Bill of Rights as a whole. ${ }^{38}$ In the matter currently under discussion, the question at issue is whether the differentiation in pensionable age in terms of the SAA is unreasonable. Whereas the Khosa case dealt with discrimination on the basis of citizenship, the applicants in the case under discussion contended that the only reason that they were denied access to the social assistance scheme was that they are male. Section 9(3) of the Bill of Rights lists sex as one of the grounds of differentiation in terms of which the presumption of unfairness provided for in section 9(5) will arise. Other than what was the case in Khosa, the unfairness of the differentiation is presumed and the State would, therefore, be required to prove otherwise.

In the case of Roberts and Others $v$ Minister of Social Development and Others, ${ }^{39}$ the Minister of Social Development, Director-General of Social Development and the MEC for Social Development, Eastern Cape, ${ }^{40}$ raised the following arguments (among others) worth noting for this discussion:

a) They argued that the applicants' arguments are based on formal equality and that a substantive notion of equality should be used instead. Therefore, in their view, the applicants' argument can only apply to

33 Section 9 of the Constitution.

34 Government of the Republic of South Africa and Others $v$ Grootboom and Others 2001 (1) SA 46 (CC) 61 paras 21-22.

35 According to the SANGOCO Report on poverty and human rights 1997-1998, the 'other measures' to be adopted include policies, and financial, administrative, educational and social measures (5).

36 Grootboom (n 3 above) paras 42 and 44.

37 Khosa and Others $v$ Minister of Social Development and Others; Mahlaule and Another $v$ Minister of Social Development and Others 2004 (6) SA 505 (CC). The Khosa case dealt with the constitutionality of provisions of the SAA which excluded non-citizens from social assistance.

38 Khosa (supra) para 45.

39 See Roberts (n 26 above).

40 Answering affidavit by the acting Director-General of the Department of Social Development, C Pakade, on behalf of the abovementioned respondents. 
persons who are 'similarly situated', but not in this case where the persons are not 'similarly situated'. ${ }^{41}$

b) As regards their position in society, men as a group generally were not the victims of unfair discrimination in the past to the same extent as women were. ${ }^{42}$

c) Women in the rural areas are rated as facing the worst socio-economic challenges as compared to other population groups. ${ }^{43}$ The large number of woman headed households in rural areas initially was largely due to the migrant labour system that had men leaving for urban areas to work. ${ }^{44}$ Black women were denied the opportunities to build decent lives for themselves during the apartheid years, as they were forced to live off the land in the rural areas. Although the legal obstacles to equal opportunities have been removed, many black women still suffer under the legacy of poverty and the 'poorest of the poor are still living under extremely trying conditions' ${ }^{45}$ The older person's grant is, therefore, rightly targeted at older black women in the rural areas. ${ }^{46}$

d) Discriminatory and oppressive traditional and cultural laws and practices contribute to poverty amongst women. ${ }^{47}$ Lack of access to, and rights in, land is a major obstacle for women in overcoming poverty. ${ }^{48}$ In certain areas, such as the, Eastern Cape, the customary assumption that only men can own property, contributes to the poverty of women in those areas. ${ }^{49}$

41 Pakade (n 40 above) para 14.

42 Pakade (n 40 above) para 19.1.

43 Pakade (n 40 above) para 19.3. See also Pillay 'The Commission for Gender Equality: What is its role?' (1998) ESR Review; UN CEDAW Initial Country Report (1998) 11. South Africa's obligations in terms of Art 14 of CEDAW also require special measures of assistance for rural women. See also Mhone 'The socio-economic context and social policy needs in SA' in Olivier et al (eds) (n 31 above) 4.

44 South African Human Rights Commission Economic \& social rights report 1997-1998 'SANGOCO Report on poverty and human rights' (n 35 above) (1999) 51.

45 'Imbokodo - Women's struggle in South Africa' www.sahistory.org.za/pages/specialprojects/womensstruggle/poverty.htm (accessed 18/09/2006). According to Statistics South Africa 1997 Rural survey (1999) the adult rural population surveyed was overwhelmingly female, with the majority living in households engaged in subsistence farming.

46 Budlender Women and poverty: Executive summary (2003) 23; SANGOCO Report (n 35 above) 51.

47 Pakade (n 40 above) paras 20.1 and 20.2. See also UN Division for the Advancement of Women (UNDAW) 'Promoting women's enjoyment of their economic and social rights' Report of expert group meeting (1997) para 18; Pillay (n 43 above). The SANGOCO Report (n 35 above) recommended that government must investigate appropriate measures to eliminate discriminatory customary practices which undermine women's rights (53-54).

48 See UN CEDAW Initial Country Report (1998) 95 on how many rural African women are denied the opportunity to hold title to land. The SANGOCO Report (n 35 above) recommended that special measures and policies be introduced to facilitate women's independent access to land and credit (54).

49 Budlender (n 46 above) 3; SANGOCO Report (n 35 above) 12 and 51. In Bhe and Others $v$ Magistrate, Khayelitsha and Others; Shibi $v$ Sithole and Others; SA Human Rights Commission and Another $v$ President of the RSA and Another 2005 (1) SA 580 (CC) the Constitutional Court declared the rule of male primogeniture as applied in African customary law to the inheritance of property to be unconstitutional in as far as it hinders women and extra-marital children from inheriting property. Langa DCJ viewed the exclusion of women from inheritance on the grounds of gender to be 'a clear violation of section 9 of the Constitution' as it 'entrenches past patterns of disadvantage among a vulnerable group, exacerbated by old notions of patriarchy and male domination incompatible with the guarantee of equality under this constitutional order' (para 91). 
e) Factors, such as, child-care responsibilities, make it difficult for many women in rural, as well as urban, areas to gain employment and remain part of the paid labour force. ${ }^{50}$ Consequently, they do not have the same opportunities to accumulate retirement benefits, ${ }^{51}$ making them more vulnerable to poverty in old age. As will be highlighted below, ${ }^{52}$ women in general carry the greater burden of care-giving for all family members, children and older family members..$^{53}$ The hours spent as primary family care-giver hinder their participation in paid labour and in the running of businesses. ${ }^{54}$

f) In addition, many older women fulfil the roles of child-carers and caretakers of AIDS sufferers ${ }^{55}$ and orphans. ${ }^{56}$ A significant portion of grants received by older women is often used to support other household members, especially children. ${ }^{57}$ The great expenditure on grants for older persons has, therefore, been justified in terms of its redistributional impact. ${ }^{58}$

g) The State respondents argued that older women are to be seen 'among South Africa's most vulnerable groups' and, therefore, deserving of measures to ensure the promotion of full and equal enjoyment of their

50 Pakade (n 40 above) para 21.8. See also Budlender (n 46 above) 15 and 23. SANGOCO Report (n 35 above) 12 and 50 .

51 Moody Aging: Concepts and controversies (2000) 158.

52 See part 6 below for the discussion of Goldstone J's judgment in the Hugo case. One of the factors that led to his finding that the pardon of only the mothers of young children, and not the fathers as well, did not amount to unfair discrimination, was that fathers play a lesser role in child rearing. See also Pakade (n 40 above) para 54.3; Budlender (n 46 above) 2 and 15, where it is stated that women tend to do twice as much housework than men and are eight times more likely to be caring for ill and elderly household members. Seidman Makgetla Women and the economy (2004) 23 points out that higher income women are generally in the position to employ other persons to perform these tasks.

53 See also UNDAW (n 47 above) para 48.

54 Seidman Makgetla (n 52 above) 22 and 23. Steinberg et al Hitting home: How households cope with the impact of the HIV/AIDS epidemic (2002)15 found that up to $40 \%$ of household care-givers had to take off from work or income generating activities in order to care for sick household members.

55 The 2001 UN Declaration of Commitment on HIV/ AIDS (to which South Africa is a State Party) requires that States review the social and economic impact of HIV/ AIDS especially on women and older persons, particularly in their role as care-givers, and in families affected by HIV/ AIDS, and address their special needs. See para 68 of this Declaration. See also Combrinck and Wakefield At the crossroads: Linking strategic frameworks to address gender-based violence and HIV/ AIDS in Southern Africa (2008) $27-29$ for a discussion of this Declaration.

56 Pakade (n 40 above) para 35. See also 'Imbokodo- Women's struggle in South Africa' (n 45 above). According to Budlender (n 46 above) 16, a substantial proportion of South African children are living with neither of their parents and are probably raised by their grandmothers. She also points out that women are increasingly caring for household members other than children and ascribes this to the HIV/AIDS pandemic. Steinberg et al (n 54 above) reported that two-thirds of care-givers of AIDS sufferers are female; and $23 \%$ are older than 60 , of whom three-quarters are women (15).

57 Mhone (n 43 above) 11; Liebenberg 'The right to social security: Response' in Brand and Russell (eds) Exploring the core content of socio-economic rights (2002) 151. Steinberg et al (n 54 above) in their survey for the Kaiser Family Foundation reported on the 'growing importance of grandmothers in maintaining family groups' (of the households surveyed, one in five was headed by women over the age of 60) (12). This same survey found that grants for older persons was the second most common source of income, after formal employment, in the households surveyed (27).

58 Pakade (n 40 above) para 35. Although older person's grants are allocated to individual older persons, they 'are consumed as a household asset thus having redistributive implications.' - Hassim Gender, welfare and the developmental state in South Africa (2005) 10. See also Makino Social security policy reform in post-apartheid South Africa (2004) 1; Bhorat 'Is a universal income grant the answer?' (2002) 26 SALB 21. 
constitutional rights. They argued that older women's circumstances today reflect the effects of the structural conditions that underpin long term poverty dynamics: asset poverty, employment vulnerability, and subjection to unequal social power relations. ${ }^{59}$

Although the equalisation of pensionable age became a fait accompli with the passing of the Social Assistance Amendment Bill 10 of 2008 into an Act $^{60}$, some of the further justifications that the State could have used for retaining measures aimed specifically at assisting older women, such as, the age differentiation, also bear mentioning:

a) The majority of the population over 60 are women. ${ }^{61}$

b) Women generally live longer than men, which leaves them with a longer period after retirement to support themselves, with a greater risk of poverty in old age. ${ }^{62}$ Women are also more likely to be widowed in old age, as women tend to marry men who are older than they are and then outlive their spouses. ${ }^{63}$

c) The unemployment rate amongst women is higher than amongst men. ${ }^{64}$ This has great significance for how the income within a household is shared as

'people who bring income into a household are likely to have more decisionmaking power than other members over how the money is used. Because women are less likely to be employed than men, and tend to earn less than men when they are employed, women are likely to have less control over how the money is used'. ${ }^{65}$

d) The State is only required to take measures 'within its available resources' ${ }^{66}$ and can, therefore, not be expected to provide benefits which it cannot afford. ${ }^{67}$ It is not clear as yet what the budgetary impact of a lower pensionable age for men would be, but it is apparent that it

59 Pakade (n 40) para 37.

60 Social Assistance Amendment Act 6 of 2008.

61 Statistics South Africa Census 2001 stated the total male population aged $60-64$ as 444,510 compared to 620,784 females, and the total male population over 65 as 810,489 compared to 1404,722 females over 65. According to Moody (n 51 above) 157, women are the majority of the older population in all parts of the world.

62 Budlender (n 46 above) 23; Woolard (n 22 above) 4. Women surviving into old age in greater numbers and for more years than men is a world wide occurrence. Moody (n 51 above) 157 states that ' $[\mathrm{t}]$ he typical fate is for men to die earlier and for women to survive with chronic diseases'.

63 Moody (n 51 above) 158-9. According to Moody, older women now increasingly also feel the financial impact of divorce (159).

64 Seidman Makgetla (n 52 above) 17; UN CEDAW Initial Country Report (1998) 11; UNDAW (n 47 above) para 48. According to Budlender (n 46 above) 11 proportionately more women than men are covered by the expanded definition.

65 Budlender (n 46 above) 8.

66 Section 27(2) Constitution 1996.

67 See the Khosa case (n 34 above) para 64 where Mokgoro J acknowledges that limiting the cost of social welfare is a legitimate government concern, as long as the measures applied to keep costs in check are in accordance with the Constitution and its values. 
would lead to increased spending on older person's grants which could potentially result in budgetary shortfalls. ${ }^{68}$

e) Social assistance grants, such as, the older person's grant, are paid from tax revenue and rely on solidarity. Some authors are of the view that social solidarity is currently stretched to the limit by the existing grants as many taxpayers are resistant to what they regard as a 'culture of handouts' and dependency on the State. ${ }^{69}$ It might, therefore, stretch solidarity too far to expect taxpayers to foot the bill for grants for men from age 60 in addition to all the other grants paid. ${ }^{70}$ This argument has much in common with the concern of Goldstone $\mathrm{J}$ in the Hugo case that the release of more male prisoners would lead to a public outcry, ${ }^{71}$ and his consequent finding that the discrimination against fathers who were not released on the same terms as mothers was not unfair. ${ }^{72}$

f) The assumption that socio-economic rights are gender neutral is inaccurate, as O'Regan J remarked in the Hugo case:

'To determine whether the discrimination is unfair it is necessary to recognise that although the long-term goal of our constitutional order is equal treatment, insisting upon equal treatment in circumstances of established inequality may well result in the entrenchment of that inequality. ${ }^{73}$

Measures, such as, the older person's grant, that increase women's access to socio-economic rights are fundamental to the furtherance of gender equality. The differentiation in pensionable age between men and women has, therefore, 'added to the evidence that pensions are a gender-sensitive mechanism of redistribution'. ${ }^{74}$ The older person's grant reaches approximately $71 \%$ of older women and is regarded as a well targeted and effective measure to alleviate poverty among older

68 See Kruger (n 27 above) 13. For this reason the Taylor Committee Report (2002) 98 recommended that the retirement age of women be increased in order to achieve parity between men and women as far as retirement age is concerned, rather than recommending a decrease in the retirement age of men. The costs of incorporating 60 - 64 year old men into the older person's grant system has been estimated as between R3.3 billion (the cost as estimated by the State) and R1.164 billion per annum (the cost as calculated by the amici curiae) - see heads of argument of the amici curiae in the Roberts case (n 26 above) 22-23.

69 See Hassim (n 58 above) 19; Xulu 'In search of a new social welfare system: Is the Basic Income Grant an appropriate policy framework for developing societies? The South African case' (2005) 1 Ingede Journal of African Scholarship (available at http://ingedej.ukzn.ac.za) 10. Admittedly older persons are seen as more valid claimants than, for instance, young women - Hassim (n 58 above) 25.

70 Although admittedly the assumptions regarding the willingness of taxpayers to assist various categories of older persons have not been tested by empirical research.

71 President of the Republic of South Africa and Another $v$ Hugo 1997 (4) SA 1 (CC) 25 para 46.

72 At 26 para 47.

73 Hugo case (n 71 above) 49 at para 112

74 Hassim (n 58 above) 10. See also Sitas A 'From people's skills to people's jobs: Job creation in the greater Durban area' (1999) 16 Indicator SA 51, where he argues that any policy interventions to improve the livelihoods of people fighting poverty should be 'doubly sensitive to gender disparities'. 
women. ${ }^{75}$ Particular attention should, therefore, be paid to the obstacles that impede women in gaining access to socio-economic rights. ${ }^{76}$

The abovementioned possible justifications for a lower pensionable age for women do not apply to men as a whole, as men as a group have not suffered as a result of unfair discrimination in the past to the same extent as women. However, Kruger ${ }^{77}$ makes a good argument for those men, such as, the applicants in the Roberts case, who have become vulnerable as a result of poverty. According to her, elderly men living in poverty are in a similar position to the permanent residents that were unfairly discriminated against in the Khosa case. She argues that

'[a] statutory provision that differentiates between groups of people and disregards the vulnerability of a particular group impairs the fundamental dignity of that group. Accordingly a strong argument could be made regarding unfair discrimination as a result of the differentiation in respect of pensionable age, ${ }^{78}$

As far as the progressive realisation of the right of access to social security is concerned, the contested provision of the SAA set the pensionable ages, whereas the 1992 Act left the pensionable age open to be determined by the Minister in regulations. ${ }^{79}$ Before it was amended the legislation, therefore, did not make any provision for the discretionary lowering of the pensionable age of men and, therefore, would not have been able to facilitate greater accessibility to the older person's grant. ${ }^{80}$ This is contrary to the constitutional imperative that legislation that is passed must make it easier for people to gain access to socio-economic rights. The amendment to the SAA, and the consequent progressive lowering of the pensionable age for men, was, therefore, the only route available to improve the situation of destitute men between the ages of 60 and 64 .

In the light of the abovementioned considerations it is submitted that a clear case can be made that measures aimed specifically at assisting older women in fulfilling their social security rights are required. However, such measures have to be sensitive to the situation of older men and, with hindsight, it could be argued that the differentiation in the qualifying age for the older person's grant may not have been the most appropriate means to address the situation of older women, and that alternative measures need to be developed.

\section{SOCIAL INSURANCE FOR CARE-GIVERS}

\subsection{COIDA}

The Compensation for Occupational Injuries and Diseases Act 130 of 1993 (COIDA) provides benefits to employees or the dependents of deceased

\footnotetext{
75 Budlender (n 46 above) 25.

76 Liebenberg 'Reports of the poverty hearings' (1998) ESR Review. See also, in particular, the remark in the National Treasury Discussion paper on retirement fund reform (2004) 11 that a strong defence against this type of challenge could be found 'in the significant difference between labour market and lifetime earnings prospects of men and women'.

77 Kruger (n 27 above) 12-13.

78 At 13.

79 Regulation 2(2) R418 in GG 18771 of 31/3/98.

80 Kruger (n 27 above) 14.
} 
employee for injuries, diseases or death arising out of, and in the course of, employment. No groups of women are directly or indirectly excluded from the scope of application of this scheme, although only 'employees' are covered to the exclusion of women not formally employed due to their care-giving responsibilities. ${ }^{81}$

\subsection{Unemployment insurance}

The Unemployment Insurance Act 63 of 2001 (UIA) provides benefits to contributors who are entitled to unemployment, illness, maternity or adoption benefits, as well as benefits to dependants of deceased contributors. Benefits for all contributors are determined in terms of a sliding scale. ${ }^{82}$

Where the unemployment insurance system indirectly affects care-givers, is the credit system that determines for how long the contributor can expect benefits. The UIA system pays one day's benefits for each six days employed as a contributor ${ }^{83}$. Women who take off from work to care for family members therefore find it difficult to work enough days to secure a substantial benefit.

The UIA does contain measures to assist women in their care-giving task, specifically as far as caring for babies is concerned, in the shape of maternity benefits. ${ }^{84}$ Women who take maternity leave are, therefore, compensated for their loss of income during their pregnancy and immediately after the birth of the child. ${ }^{85}$ Women who draw maternity benefits do not forfeit their credits for unemployment and illness benefits. ${ }^{86}$

Adoption benefits are also payable to parents adopting a child under the age of two years, to a contributor who has to stop working to take care of the child. ${ }^{87}$ This benefit is specifically targeted at care-givers of small children.

Therefore, the UIA makes provision for contributors' care-giving responsibilities in specific cases, such as, maternity and adoption benefits. On the other hand, it limits the duration of benefits, such as, unemployment and illness benefits, for contributors who choose to take time off work to raise their children or take care of older family members. The reason for the limited benefits is that these (mainly female) care-givers may be precluded from working enough days to build up sufficient days' worth of credits to ensure adequate benefits.

\footnotetext{
81 See Pakade (n 40 above) para 54 for the impact of South African women's unpaid work on their labour market participation.

82 Section 12(2) read with schedules 2 and 3 UIA.

83 Section 13(3) UIA.

84 Section 24 UIA.

85 For a maximum period of 17,32 weeks, which coincides with the statutory maternity leave period.

86 Section 13(5) UIA.

87 Part E UIA.
} 


\subsection{Retirement provision}

South Africa does not have a national social insurance type retirement fund. 88 Retirement benefits are provided by a number of private occupational funds. Membership of these funds is only open to employees. ${ }^{89}$

Retirement funds can be categorised as either defined contribution (DC) or defined benefits (DB) funds. In the case of DC funds the contribution rate is specified by the rules of the fund, but the level of retirement benefits is determined by the accumulated value of contributions by both employer and employee, plus the accrued interest and other investment income credited to a specific account on behalf of the member. ${ }^{90}$ Members have no guarantees as to what amount they will receive on retirement, as various factors, such as, individual investment decisions and performance of the markets, can impact on benefits. Any factor that decreases the contributions paid, would potentially lead to a decrease in benefits. A member of a DC fund whose career is interrupted due to care-giving responsibilities, would consequently have less contributions paid on her behalf. This in return would potentially lead to a decrease in investment return and consequently a lower benefit paid.

A defined benefit (DB) fund specifies the retirement benefit to be paid. The payout formula is based on the average annual wage or salary of the member before he or she retires and on the number of years of membership of the fund..$^{91}$ The benefit paid to the retired employee will, therefore, be a proportion $^{92}$ of final earnings multiplied by the number of years of membership of the fund. Where a care-giver stops working or never works as a result of her care-giving responsibilities, the number of 'years worked' part of the formula would be lower and, therefore, the care-giver would be entitled to less benefits on retirement.

It can, therefore, be concluded that, in the case of both DC and DB funds, the method of determining benefits builds in a penalty for care-givers who take off from work for family care-giving. With DC funds, they have less opportunity to contribute, whereas with DB funds, they work less years. As a consequence, their care-giving role could lead to financially insecure retirement years.

88 The South African government has started the process to create a National Pension Fund. See National Treasury Social security and retirement reform. Second discussion paper (2007) 1.

89 Self-employed and professional persons save for retirement through the purchase of private retirement insurance products. The Pension Funds Act 24 of 1956 regulates the occupational retirement funds.

90 Section 1 Pension Funds Act 24 of 1956.; World Bank Averting the old age crisis (1994) xxi; OECD Maintaining prosperity in an ageing society (1998) 128.

91 James 'New models for old-age security' (1998) 13 World Bank Research Observer 274.

92 Called the accrual factor or accrual rate. The accrual factor is the fraction of salary which a member accrues for every year of service. 


\subsection{Conclusion regarding women care-givers and social insurance}

Care-giving responsibilities could, depending on the circumstances, lead to women being excluded from being employees and consequently from the scope of application of many formal social insurance schemes. Due to this marginalised position, many women have no choice but to turn to informal social security. ${ }^{93}$ This does not necessarily constitute a disadvantage as long as suitable informal social security is available. The advantage of informal social security is that it is suited to the needs of the members of the particular scheme. On the other hand, informal social security schemes are unregulated and generally provide lower benefits than formal schemes.

In conclusion, care-givers are excluded from social insurance for two reasons. First, because they are in many instances excluded from the scope of application of the schemes since they are not regarded as employees. Secondly, as they experience difficulty in meeting the requirements for length of time worked in order to maintain the maximum benefit available, ${ }^{94}$ they receive little to no social insurance benefits and are relegated to relying on the State for grants.

Having determined that there are some concerns regarding the treatment of care-givers in South African social security legislation, it becomes necessary to examine the extent to which South Africa complies with international law or regional legislation, with regard to women and their care-giving responsibilities, that it either has signed or signed and ratified.

\section{INTERNATIONAL AND REGIONAL LAW}

\subsection{CEDAW and female care-givers}

The Convention on the Elimination of All Forms of Discrimination (CEDAW) ${ }^{95}$ adopted in 1979, and ratified by South Africa in 1995, makes provision for equality in social security benefits.

Article 11 of CEDAW refers to elimination of discrimination in the field of employment. It makes provision for equal social security rights, particularly in cases of retirement, unemployment, sickness, invalidity and old age and other incapacity to work. ${ }^{96}$ To preserve women's right to work they are to be protected against loss of benefits due to marriage or pregnancy. Of particular interest to women raising children, is the requirement that State Parties should implement measures

'to encourage the provision of the necessary supporting social services to enable parents to combine family obligations with work responsibilities and participation in public life,

93 Informal social security is the less regulated counterpart of formal social security and consists of measures that can be described as either neighbourhood and informal sector based social support or kinship or family based support - see Dekker and Olivier 'Informal forms of social security and informal sector social security' in Olivier et al (eds) (n 2 above) 83-99.

94 For unemployment and retirement benefits.

95 GA res. 34/180, 34 UN GAOR Supp. (No. 46) at 193, UN Doc A/34/46, entered into force September 3, 1981 .

96 Article 11(1)(e) CEDAW. 
in particular through promoting the establishment and development of a network of child-care facilities'.97

In respect of women in rural areas, CEDAW makes specific reference to the contribution made by rural women as far as the economic survival of their families is concerned, and requires State Parties to provide for measures that give rural women direct access to social security benefits. ${ }^{98}$

Measured against the CEDAW requirements, South African provision for the rights of female care-givers falls short by a good measure. As was illustrated above, working women who choose to take time off work to raise their children, do so with the knowledge that they would have to sacrifice a significant portion of their social insurance benefits. Far from making special provision for rural women, the current social security system relegates them to beneficiaries of State grants.

\subsection{African and regional protection for women care-givers}

Both the Protocol to the African Charter on Human and Peoples' Rights on the Rights of Women in Africa (African Women's Protocol) ${ }^{99}$ and the Southern African Development Community Protocol on Gender and Development (SADC) Gender Protocol ${ }^{100}$ contain various provisions which require State Parties to take cognisance of women's role as care-givers, and to enact specific social security measures to assist women in their duties as care-givers. It should be noted that South Africa ratified the African Women's Protocol on 17 December 2004 and that the SADC Gender Protocol was signed in August 2008.

\subsubsection{The African Women's Protocol}

Article 2(1)(d) of the African Women's Protocol requires State Parties to 'take corrective and positive action in those areas where discrimination against women in law and in fact continues to exist'. In other words, this Protocol requires that the State takes action to ensure that substantive equality is reached between men and women. Article 13 is more specific in that it requires State Parties to enact legislation and other measures to guarantee women equal opportunities in work, career advancement and other economic opportunities. This Article requires States inter alia: (1) to create conditions to promote and support the occupations and economic activities of women, in particular, within the informal sector; ${ }^{101}$ (2) to establish a system of protection and social insurance for women working in the informal sector and to sensitise them to adhere thereto; ${ }^{102}$ (3) to take necessary measures to rec-

\footnotetext{
97 Article 11(2)(c).

98 Article 14.

99 Adopted by the 2nd Ordinary Session of the Assembly of the Union, in Maputo, Mozambique, on 11 July 2003.

100 Adopted and signed by SADC Heads of States during August 2008. See www.genderlinks.org.za for further information regarding this Protocol (accessed 26/9/2008).

101 Article 13(e).

102 Article 13(f).
} 
ognise the economic value of the work of women in the home; ${ }^{103}$ and (4) to recognise that both parents bear the primary responsibility for the upbringing and development of children, and that this is a social function for which the State and the private sector have secondary responsibility. ${ }^{104}$

Article 13 thus requires expressly that State Parties implement various policies to ensure that women are economically protected, even for the work they do at home, which is largely contained in their care-giving responsibility towards the rest of their family. This Article would, therefore, assist State Parties in also complying with their duties to take positive action to eliminate discrimination against women, in terms of Article 2 of the African Women's Protocol. Substantive equality requires that the State take positive actions to alleviate the inherent discrimination that women face, especially when their right to human dignity is infringed by being dependant on other people.

Article 13 deals with the situation where women are capable of working (in terms of age), but, at the same time, are not capable of working, because of various social factors, one being their care-giving responsibility. Article 22, on the other hand, deals specifically with 'special protection of elderly women'. In terms of this Article State Parties undertake to 'provide protection to elderly women and take specific measures commensurate with their physical, economic and social needs as well as their access to employment and professional training. ${ }^{105}$ State Parties are thus required to take specific measures to protect older women, especially with regards to their economic and social needs. Even though the State must also take the specific circumstances of older men into account, it is women who mostly constitute being care-givers and who receive no formal social insurance benefits to save for retirement. This would, therefore, justify why special protection should be granted to older women, as opposed to taking the specific circumstances of all older people into account.

\subsubsection{The SADC Gender Protocol}

Unlike the African Women's Protocol, the SADC Gender Protocol contains more definitions and also has a specific definition of 'care-giver'. For the purposes of this Protocol 'care-giver' means 'any person who provides emotional, psychological, economic, spiritual or social care and support services to another'. ${ }^{106}$ This definition is quite broad as it opens the door to anyone to be a care-giver of another. It also does not address the personal nature of the relationship between a care-giver and the person receiving the care.

The SADC Gender Protocol is quite progressive and unsatisfactory at the same time. It is unsatisfactory because it does not expressly address the needs of older women within the Southern African context. 
On the other hand, it is quite progressive, because it deals in depth with women's constitutional and legal rights; ${ }^{107}$ governance; 108 education and training; ${ }^{109}$ productive resources and employment; ${ }^{110}$ gender based violence; ${ }^{111}$ health and HIV \& AIDS; ${ }^{112}$ peace building and conflict resolution; ${ }^{113}$ and media, information and communication. ${ }^{114}$

Article 16 of this Protocol requires State Parties to 'adopt policy measures to ease the burden of the multiple roles played by women'. In other words, this Protocol acknowledges that women serve in various roles within society. State Parties can ease this burden placed on women by enacting appropriate social insurance and social assistance legislation and adopting appropriate policies.

Article 27 of the SADC Gender Protocol deals specifically with women as care-givers. Article 27(3)(c) states that

'State Parties shall, by 2015 develop and implement policies and programmes to ensure appropriate recognition of the work carried out by care-givers, the majority of whom are women, the allocation of resources and psychological support for care-givers as well as promote the involvement of men in the care and support of people living with HIV and AIDS'.

This Article thus rightly acknowledges that the majority of care-givers are women. Their care-giving role unfortunately obstructs them from finding formal employment, which would assist them to save for retirement. Thus, measures should be enacted to assist women in caring for those infected with HIV and AIDS, especially older women who use their social assistance to take care of family members infected with various diseases. ${ }^{115}$

It can thus be concluded that the various international and regional documents mentioned above indeed provide room for special measures to be created to advance women's access to social insurance and social assistance for older persons. It is now up to the State to focus on, create and implement legislation and policies to fulfil its obligation in terms of these international documents which it adopted and ratified.

Before making any concluding argument, one remaining obstacle in the way of measures intended to address the marginalisation of women with

\section{Part 2.}

108 Part 3.

109 Part 4.

110 Part 5.

111 Part 6.

112 Part 7.

113 Part 8.

114 Part 9

115 In terms of Art 68 of the UN Declaration of Commitment on HIV/ AIDS, State Parties were to enact social security measures, among others, for women and the elderly who are care-givers of people who suffer from HIV/ AIDS. This was to be done by 2003. In its 2006 Report to the UN Special Session on HIV/ AIDS, South Africa stated that women and youth receive stipends for their role as care-givers of those who suffer from HIV/ AIDS, but only where they are involved in a community project. It should also be noted that only in the instance where a woman is the care-giver of a child (HIV positive or negative) can she receive social assistance for caring for this child (provided that she passes the means test). Therefore, South Africa still lacks social assistance for care-givers where they are taking care of other family members infected with HIV/ AIDS, other than children. 
care-giving responsibilities, ie the important caution against stereotyping women in a care-giving role, needs to be addressed.

\section{CAUTION AGAINST STEREOTYPING WOMEN IN CARE- GIVING ROLE}

The instances provided above where women who happen to fulfil a care-giving role may be marginalised with regard to social insurance benefits, cannot be used en bloc to establish that women's care-giving role will under all circumstances adversely affect their social security benefits. Whether the care-giving sacrifices of women of working age should be the basis of preferential treatment for women has been the subject of vigorous debate, specifically in the light of the recent case regarding the equalisation of pensionable age for men and women, as has been illustrated above.

The Constitutional Court had occasion to decide on the issue of discrimination on the basis of sex or gender and the pitfalls of gender stereotypes, in President of the Republic of South Africa and Another v Hugo ${ }^{116}$. President Mandela had decided to grant a special remission of sentence to mothers of young children under the age of 12 years $^{117}$ to mark the occasion of his inauguration. The President acted in terms of his powers under section 82(1) (k) of the interim Constitution ${ }^{118}$ and signed the Presidential Act 17 of 27 June 1994, in terms of which the sentences were remitted. The respondent applied to the High Court to have the Presidential Act declared unconstitutional in that it unfairly discriminated on the grounds of sex against him as a father, and not a mother, of a minor child under the age of 12 years. The High Court held that the Presidential Act was unconstitutional and gave the President six months to correct the Act.

Section 8 of the interim Constitution ${ }^{119}$ provided that no person shall be unfairly discriminated against on the grounds of, amongst others, gender and sex. ${ }^{120}$ In terms of section 8(4) prima facie proof of discrimination on any of the grounds listed in subsection (2) shall be presumed to be sufficient proof of unfair discrimination, until the contrary is proven.

In the appeal to the Constitutional Court, it had, first, to determine whether there was discrimination in terms of section $8(2)$, and, once this was established, whether this was sufficient proof of unfair discrimination in terms of section $8(4) .{ }^{121}$

Central to the majority judgment was the view that mothers play a special role in caring for and nurturing young children, more so than fathers. Of

\footnotetext{
116 See (n 71 above).

117 Mothers of young children constitute one category to whom special remission of sentence was granted; the other two categories were children younger than 18 , and disabled prisoners.

118 Act 200 of 1993.

119 Section 8 of the interim Constitution is the forerunner to the equality clause in s 9 Constitution 1996.

120 Section $8(2)$.

121 Unless the President could discharge the onus placed upon him by s $8(4)$ and prove that the discrimination was not unfair.
} 
specific interest was Goldstone J's agreement with the view that ' $[t]$ he result of being responsible for children makes it more difficult for women to compete in the labour market and is one of the causes of the deep inequalities experienced by women in employment'. ${ }^{122}$ It appeared from the evidence led that the President had relied on the generalisation that mothers carry the greater financial and social burden of child rearing in deciding to pardon only the mothers of young children, and not the fathers as well.

The fact that the persons complaining of discrimination in a specific case are not members of a historically disadvantaged group does not necessarily mean that the impact of the discrimination was not unfair on them. Goldstone J stated that the goal of equal treatment, which lies at the base of the prohibition of unfair discrimination, cannot be achieved

'by insisting upon identical treatment in all circumstances before that goal is achieved. Each case, therefore, will require a careful and thorough understanding of the impact of the discriminatory action upon the particular people concerned to determine whether its overall impact is one which furthers the constitutional goal of equality or not. A classification which is unfair in one context may not necessarily be unfair in a different context'. ${ }^{123}$

He also stated that the nature of the interests which have been affected by the discrimination will be a determining factor in deciding whether the discrimination was unfair. ${ }^{124}$ The factors that led Goldstone J to hold that the President had discharged the burden placed upon him by section 8(4), and, therefore, to a finding that the discrimination against fathers who were not released on the same terms as mothers was not unfair, ${ }^{125}$ were:

- As there are many more male than female prisoners, a release of all fathers would have led to a release of a large number of male prisoners.

- Release of male prisoners would not have had the same impact on children, as many fathers play a lesser role in child rearing.

- The release of more male prisoners might have led to a public outcry. ${ }^{126}$

Kriegler I dissented on the basis of how the majority applied the equality clause to the facts of the case. His decision was based on the opinion that the presumption of unfairness of discrimination based on gender had not been rebutted. In his view the majority erred in taking into consideration factors over which insufficient data was available, such as, the effect on the public of the release of male prisoners. ${ }^{127} \mathrm{He}$ specifically took issue with the notion relied upon by the President to release only mothers of young children, namely, that women are to be regarded as the caretakers of young children. He regarded this notion as

122 At 22 para 38. This view has also since been echoed by authors, such as, Budlender (n 46 above) 15.

123 Hugo case 1997 (n 71 above) 23 para 41.

124 At 23-24 para 43.

125 At 26 para 47 .

126 At 25 para 46.

127 At 34 para 72. 
'both a result and a cause of prejudice: a societal attitude which relegates women to a subservient, occupationally inferior yet unceasingly onerous role. It is a relic and a feature of the patriarchy which the Constitution so vehemently condemns. Section 8 and the other provisions mentioned above outlawing gender or sex discrimination were designed to undermine and not to perpetuate patterns of discrimination of this kind... Reliance on the generalisation that women are the primary care givers is harmful in its tendency to cramp and stunt the efforts of both men and women to form their identities freely'. ${ }^{128}$

In his view the perpetuation of the social stereotype that a woman's place is at home will be a burden on all South African women and consequently outweighs any advantages to the small group of women to benefit from the pardon. ${ }^{129} \mathrm{He}$ found that the presumption of unfairness of discrimination was not rebutted in this case, and that the Presidential Act was unconstitutional to the extent that it discriminated between male and female prisoners with minor children under the age of 12 years. ${ }^{130}$

Like Kriegler J, Mokgoro J also differed from the majority of her colleagues over the application of the test as to whether discrimination was unfair on the facts of the case. She also questioned the gender stereotyping which led to the decision to release female prisoners and not male prisoners as well. In her opinion the effect of this gender stereotyping is as follows:

'In my view, denying men the opportunity to be released from prison in order to resume rearing their children, entirely on the basis of stereotypical assumptions concerning men's aptitude at child rearing, is an infringement upon their equality and dignity. The Presidential Act does not recognise the equal worth of fathers who are actively involved in

128 At 37 para 80 . The existence of gender stereotypes about the roles of men and women and family forms has also been confirmed in reports, such as, Budlender (n 46 above) 4 where it is stated that these assumptions envisage 'a neat nuclear family in which the man works and earns money, while the woman (his wife) does the housework and looks after the children'.

129 The Judge says (38 para 83):

'In truth there is no advantage to women qua women in the President's conduct, merely a favour to perceived child minders. On the other hand, there are decided disadvantages to womankind in general in perpetuating perceptions foundational to paternalistic attitudes that limit the access of women to the workplace and other sources of opportunity. There is also more diffuse disadvantage when society imposes roles on men and women, not by virtue of their individual characteristics, qualities or choices, but on the basis of predetermined, albeit time-honoured, gender scripts. I cannot agree that, because a few hundred women had the advantage of being released from prison early, the Constitution permits continuation of these major societal disadvantages'.

See also 39 para 85 where he states that

'the President's ipse dixit establishes that the decision was founded on what has come to be known as gender stereotyping. And the Constitution enjoins all organs of State - here the President - to be careful not to perpetuate the distinctions of the past based on gender type-casting. In effect the Act put the stamp of approval of the head of State on a perception of parental roles that has been proscribed. Mothers are no longer the 'natural' or 'primary' minders of young children in the eyes of the law, whatever tradition, prejudice, male chauvinism or privilege may maintain. Constitutionally the starting point is that parents are parents'.

130 Although O'Regan J agreed that one of the primary sources of women's disadvantage in South Africa is the unequal division of labour between fathers and mothers, she found Kriegler I's approach to whether reliance on a generalisation led to unfair discrimination too restrictive. She held that:

'With respect, therefore, I cannot agree with Kriegler J that it is a "profound and troubling" disadvantage for women when the President says that mothers play a special role in nurturing children. The profound disadvantage lies not in the President's statement, but in the social fact of the role played by mothers in child rearing and, more particularly, in the inequality which results from it.' She found that the discrimination did not cause any significant harm to women in general and that the impact on fathers was far from severe. The discrimination was, therefore, held not to be unfair (50 paras $114-115)$. 
nurturing and caring for their young children, treating them as less capable parents on the mere basis that they are fathers and not mothers.

Section 8 of our Constitution gives us the opportunity to move away from gender stereotyping. Society should no longer be bound by the notions that a woman's place is in the home (and, conversely, not in the public sphere), and that fathers do not have a significant role to play in the rearing of their young children. Those notions have for too long deprived women of a fair opportunity to participate in public life, and deprived society of the valuable contribution women can make. Women have been prevented from gaining economic self-sufficiency, or forging identities for themselves independent of their roles as wives and mothers. By the same token, society has denied fathers the opportunity to participate in child rearing, which is detrimental both to fathers and their children. ${ }^{131}$

She, therefore, found that the fathers who were not released were indeed unfairly discriminated against. ${ }^{132}$ However, for reasons very similar to those that led Goldstone J to conclude that the discrimination in casu was fair, she found that the Presidential Act was justified in accordance with the requirements of section 33(1) of the interim Constitution. ${ }^{133}$

The significance of the Hugo case for the question of whether measures aimed at improving access to social security for female care-givers would withstand constitutional scrutiny is twofold: first, for the different views on the application of the test on whether discrimination is unfair; ${ }^{134}$ and, secondly, for the instructive, yet diverse approaches regarding gender stereotyping and its impact on the fairness of discrimination. Despite the fact that the Hugo case precedes the test for unfair discrimination established in the Harksen case $^{135}$, the similarities of the underlying issues, such as, gender stereotyping, require a careful consideration of the various approaches in the Hugo case. On the one hand, the view is held that women need additional protection as a result of being marginalised by apartheid and patriarchy, and, on the other,

131 At 41-2 paras 92-93.

132 At 42 para 94.

133 At 48 para 106. Section 33 of the interim Constitution was the equivalent of s 36 of the Constitution 1996.

134 To be read in conjunction with the unfair discrimination jurisprudence established in Harksen $v$ Lane NO and Others 1998 (1) SA 300 (CC) and the Khosa case (n 37 above).

135 At 1511 para 53 the test was outlined as:

'(a) Does the provision differentiate between people or categories of people? If so, does the differentiation bear a rational connection to a legitimate government purpose? If it does not then there is a violation of $\mathrm{s} 8(1)$. Even if it does bear a rational connection, it might nevertheless amount to discrimination.

(b) Does the differentiation amount to unfair discrimination? This requires a two-stage analysis:

(i) Firstly, does the differentiation amount to 'discrimination'? If it is on a specified ground, then discrimination will have been established. If it is not on a specified ground, then whether or not there is discrimination will depend on whether, objectively, the ground is based on attributes and characteristics which have the potential to impair the fundamental human dignity of persons as human beings or to affect them adversely in a comparably serious manner.

(ii) If the differentiation amounts to 'discrimination', does it amount to 'unfair discrimination'? If it has been found to have been on a specified ground, then unfairness will be presumed. If on an unspecified ground, unfairness will have to be established by the complainant. The test of unfairness focuses primarily on the impact of the discrimination on the complainant and others in his or her situation.

(c) If the discrimination is found to be unfair then a determination will have to be made as to whether the provision can be justified under the limitations clause (section 33 of the interim Constitution).' 
the notion is expressed that gender stereotyping is not a sound foundation to address the problems of a vulnerable group. ${ }^{136}$ Even though Kriegler and Mokgoro IJ raised valid arguments with regards to stereotyping women into care-giving roles, they failed to address the social reality of the ostensible duties placed on women.

A distinction should be drawn between gender stereotypes and statistics proving that women in general, and women in care-giving roles in particular, are deserving of special protection. The majority view of the Constitutional Court in Hugo demonstrates that in the Court's view, facts and statistics on the impact of the care-giving role of women outweigh the danger of stereotyping. ${ }^{137}$

\section{CONCLUSION}

The caution against stereotyping women as care-givers ${ }^{138}$ ignores the reality that women may forfeit social insurance benefits as a result of their caregiving responsibilities and the fact that family care-givers are not regarded as employees for the purposes of social insurance.

It has been shown that women's care-giving role and their inability to make provision for their own retirement were some of the factors that led to the differentiation of the pensionable age for the older person's grant. The equalisation of pensionable age for both genders at age 60 may indeed be an advance for men between the ages of 60 and 64 who qualify in terms of the means test. However, it is submitted that the fact that the one provision that attempted to advance the cause of older women, and therefore, also many female care-givers, has now fallen away. A substantive equality approach would require that special steps are taken to address the inequality faced by older women as a result of not being able to save for their retirement via social insurance means. These should be seen as steps to promote equality. ${ }^{139}$

Brodsky and Day argue that one of the reasons why women are economically unequal to men is because women's work is not properly valued. ${ }^{140}$ As

136 MacKinnon 'Sex equality under the Constitution of India: Problems, prospects, and personal laws' in MacKinnon Are women human? And other international dialogues (2006) 126 argues that when trying to establish whether a particular group was historically disadvantaged, a factual inquiry needs to take place. This inquiry would require of courts to investigate the reality of the social hierarchy [between the groups] and not to ignore it.

137 See, however, Albertyn and Goldblatt 'Facing the challenge of transformation: Difficulties in the development of an indigenous jurisprudence of equality' (1998) 14 SAJHR 264-265, who express the view that the judgments are flawed due to the failure to take the social context of the applicant into consideration, and to regard him as part of the sub-group of disadvantaged primary care-giver parents rather than grouping him with fathers in general.

138 See the discussion of the minority judgment in the Hugo case (n 71 above) in part 6 above.

139 MacKinnon (n 137 above) 127.

140 Brodsky \& Day ‘Denial of the means of subsistence as an equality violation' in Murray \& O'Sullivan Advancing women's rights (2005) 152-153 state: 'The fact that women are economically unequal to men and more likely to be poor is not mere coincidence. It is the result of women's work not being properly valued; of women being penalized because they are the principal care-givers of children, old people, men and those who are ill or disabled; and of systemic discrimination in the workforce which devalues the work of women, and marginalises women workers who are aboriginal, of colour, immigrants or disabled.' 
long as female care-givers are (even only indirectly) denied access to social insurance and are relegated to a position where they are dependent on the State for grants or on informal social security structures, they will remain marginalised. The position of female care-givers must be addressed in a manner sensitive to both male and female care-givers without diluting the focus on the marginalisation of female care-givers.

\section{BIBLIOGRAPHY}

Combrinck $\mathrm{H}$ and Wakefield L At the crossroads: Linking strategic frameworks to address gender-based violence and HIV/AIDS in Southern Africa (2008) Bellville: Community Law Centre, UWC

Committee of Inquiry into a Comprehensive System of Social Security for South Africa (Taylor Committee) Transforming the present - protecting the future (2002)

MacKinnon CA Are women human? And other international dialogues (2006) Cambridge MA: Harvard University Press

Makino K Social security policy reform in post-Apartheid South Africa - A focus on the Basic Income Grant (2004), Durban: Centre for Civil Society, UKZN (Research report No. 11)

Moody H R Aging: Concepts \& controversies (3 ed) (2000) Thousand Oaks CA: Pine Forge Press

Murray C and O'Sullivan M (eds) (2005) Advancing women's rights (2005) Cape Town: Juta and Company

National Treasury Social security and retirement reform Second discussion paper (2007)

OECD Maintaining prosperity in an ageing society (1998) Paris OECD Publishing

Olivier MP, Kalula E, Van Steenberge J, Jorens Y and Van Eeckhoutte W (eds) The extension of social security protection in South Africa (2001) Cape Town: Siberlink

Olivier MP, Smit N, Kalula ER and Mhone GCZ (eds) Introduction to social security (2004) Durban: LexisNexis Butterworths

Olivier MP et al (eds) Social security A legal analysis (2003). Durban: LexisNexis Butterworths

Pieters D Introduction into the basic principles of social security (1993) Deventer: Kluwer

Seidman Makgetla N Women and the economy (2004) (Paper prepared for the Genderstats Project)

South African Human Rights Commission Economic \& social rights report 1997-1998 Vol V 'SANGOCO's Report on poverty and human rights' (1999)

Steinberg $\mathrm{M}$ et al Hitting home: How households cope with the impact of the HIV/AIDS epidemic (2002) The Kaiser Family Foundation 
The Presidency National report on the status of older persons 1994-2002 (2002) (Report to the Second World Assembly on Ageing - Madrid, Spain)

UN CEDAW Initial report of States parties: South Africa CEDAW/C/ZAF/1 (1998)http://www.un.org/womenwatch/daw/cedaw/reports.htm\#s(accessed 22/10/2008)

United Nations Division for the Advancement of Women Promoting women's enjoyment of their economic and social rights (1997) (Report of Expert Group Meeting, Finland)

Woolard I Impact of government programmes using administrative data sets: Social assistance grants (2003) (Project 6.2 of the Ten Year Review Research Programme) (available at http://www.sarpn.org.za/documents/d0000946/ P1041-Woolard_10year_June2003.pdf)

World Bank Averting the old age crisis: Policies to protect the old and promote growth (1994) New York: Oxford University Press: (also available at http:// go.worldbank.org/OE6RWFN10) 